\title{
Atypical herpetic keratitis presenting as multifocal epithelial lesions
}

Virgilio Galvis, Alejandro Tello

Centro Oftalmológico Virgilio Galvis, Floridablanca, Colombia

Fundación Oftalmológica de Santander FOSCAL, Floridablanca, Colombia

Departmento de Oftalmología, Facultad de Ciencias de la Salud, Universidad Autónoma de

Bucaramanga, Bucaramanga, Colombia

Humans are the only natural reservoir for herpes simplex virus 1 , which can invade its host after contacting mucosal surfaces or through abraded skin. Primary infection, either ocular or extraocular, manifests clinically only in a percentage of people yet to be determined, considered to be less than $20 \%$. Therefore, since approximately $80 \%$ of patients are asymptomatic, the infection can spread without being recognized most of the time.

Following primary infection, the virus establishes in sensory neurons where it remains for the lifetime of the host. Upon reactivation, the virus reappears, usually at the mucocutaneous junction of the lips, causing herpes labialis, commonly known as cold sores or fever blisters. However, following reactivation, the virus rarely involves the ophthalmic branch of the trigeminal nerve and causes ocular disease, including keratitis (1-6).

A 60-year-old woman presented with red eye, a foreign body sensation, and moderate photophobia in the right eye for one week. She was receiving a combination of antibiotics and topical steroids prescribed by a general practitioner.

Upon examination in the slit lamp, four separate dendritic-shaped epithelial lesions highly suggestive of epithelial herpetic keratitis were found. However, the lesions presented with a multifocal compromise, which is a very uncommon presentation since these corneal epithelial ulcers are usually single lesions of variable size (figure 1). One factor that could have led to this atypical presentation was the use of topical dexamethasone. Since the 1960s, it has been considered that steroids are contraindicated when there is corneal epithelial compromise caused by herpes simplex virus (7-11) and that the use of steroids in epithelial herpetic keratitis increases the risk of the ulcer progressing from a dendritic ulcer

Received: $12 / 04 / 2020$

Accepted: 22/07/2020

Published: 24/07/2020

\section{Citation:}

Galvis V, Tello A. Atypical herpetic keratitis presenting as multifocal epithelial lesions. Biomédica 2020;40:585-6.

https://doi.org/10.7705/biomedica.5518

\section{Corresponding author:}

Alejandro Tello, Centro Oftalmológico Virgilio Galvis, FOSCAL Internacional, Office 3011, Floridablanca, Colombia

Telephone: (577) 6392929

alejandrotello@gmail.com

\section{Author contributions:}

Virgilio Galvis and Alejandro Tello: Conception, revision and final approval

Alejandro Tello: Drafting of the manuscript

\section{Funding:}

This manuscript was not funded by any institution.

Conflicts of interest:

The authors declare that they have no conflicts of interest. to a geographical ulcer and the possibility of multifocality $(10,11)$.

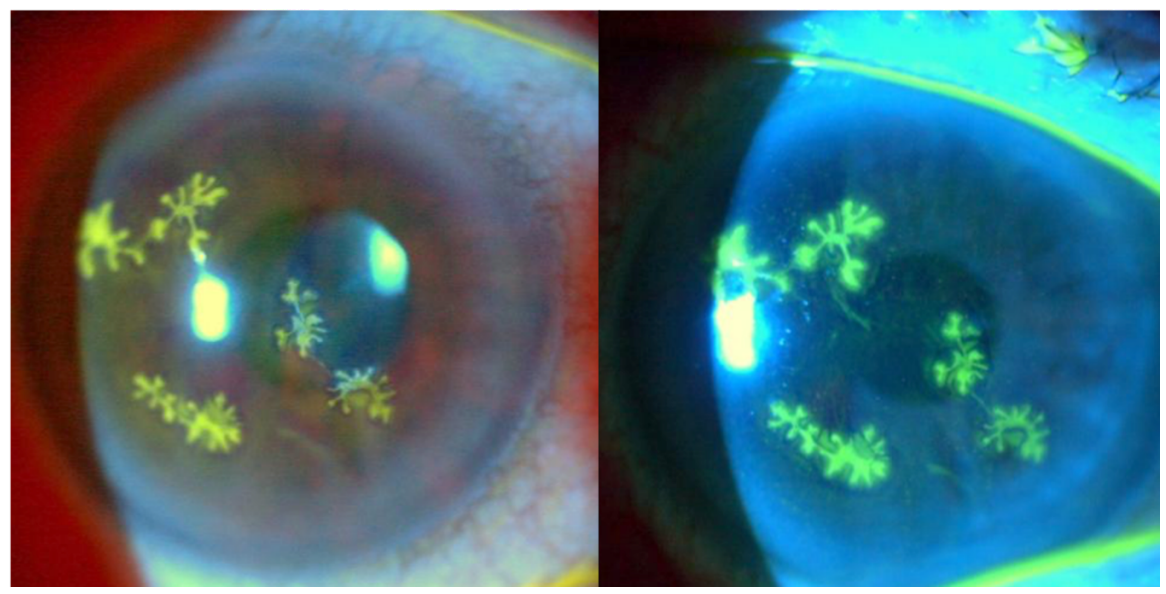

Figure 1. Multiple dendritic epithelial ulcers stained with fluorescein in a 60 -year-old woman who received topical steroids prescribed by a general practitioner. Clinical photographs in a slit lamp illuminated with white light (left) and using a cobalt blue filter (right) 
This case reaffirms the probability that the use of these substances can worsen the clinical picture when the virus is compromising the epithelium. Therefore, since this condition can be confused with infectious conjunctivitis, general practitioners should be cautious and look for symptoms such as photophobia, which would suggest corneal involvement. The use of topical steroids should be avoided, since these drugs can aggravate the ocular affectation caused by the herpes virus, as in this case.

Keywords: Keratitis; herpetic eye disease; herpes simplex; cornea; corticosteroids.

Palabras clave: queratitis, enfermedad ocular herpética, herpes simplex, córnea, corticosteroides.

\section{References}

1. Seitz B, Heiligenhaus A. Das Chamäleon der Keratitis herpetischer Genese - Diagnose und Therapie. Klin Monbl Augenheilkd. 2015;232:745-53. https://doi.org/10.1055/s-0035-1545975

2. Al-Dujaili LJ, Clerkin PP, Clement C, McFerrin HE, Bhattacharjee PS, Varnell ED, et al. Ocular herpes simplex virus: How are latency, reactivation, recurrent disease and therapy interrelated? Future Microbiol. 2011;6:877-907. https://doi.org/10.2217/fmb.11.73

3. Tsatsos M, MacGregor C, Athanasiadis I, Moschos MM, Hossain P, Anderson D. Herpes simplex virus keratitis: An update of the pathogenesis and current treatment with oral and topical antiviral agents. Clin Exp Ophthalmol. 2016;44:824-37. https://doi.org/10.1111/ceo.12785

4. Harris KD. Herpes simplex virus keratitis. Home Health Now. 2019;37:281-4 https://doi.org/10.1097/NHH.0000000000000791

5. Rowe AM, St Leger AJ, Jeon S, Dhaliwal DK, Knickelbein JE, Hendricks RL. Herpes keratitis. Prog Retin Eye Res. 2013;32:88-101. https://doi.org/10.1016/j.preteyeres.2012.08.002

6. Galvis V, Tello A, Revelo ML, Carreño NI. Herpes simplex virus keratitis: Epidemiological observations. Surv Ophthalmol. 2013;58:286-7. https://doi.org/10.1016/i.survophthal.2013.02.003

7. Thygeson P, Hogan MJ, Kimura SJ. The unfavorable effect of topical steroid therapy on herpetic keratitis. Trans Am Ophthalmol Soc. 1960;58:245-62.

8. Patterson A, Jones BR. The management of ocular herpes. Trans Ophthalmol Soc U K. 1967;87:59-84

9. Patterson A. Management of ocular herpes simplex. Br J Ophthalmol. 1967;51:494-5. https://doi.org/10.1136/bjo.51.7.494

10. Roozbahani M, Hammersmith KM. Management of herpes simplex virus epithelial keratitis. Curr Opin Ophthalmol. 2018;29:360-4. https://doi.org/10.1097/ICU.0000000000000483

11. Prakash G, Avadhani K, Srivastava D. The three faces of herpes simplex epithelial keratitis: A steroid-induced situation. BMJ Case Rep. 2015;2015:bcr2014209197. https://doi.org/10.1136/bcr-2014-209197 